question the band council's legitimacy. But, what is it that makes GNEG more representative? From what does GNEG derive merit? What legitimates the voice of Willow's "three sisters from Grassy Narrows" (184)? While community tension was clearly evident, Willow favours scrutinizing community dynamics while rarely questioning what she views as "traditional" power.

One of Willow's central interests is in cultural revitalization. She makes the threat of clearcutting to cultural practices clear, but the material consequences are not always explicit. She says little about how clearcutting can destroy animal habitat, reduce trappers' access to trap lines, or destroy traps themselves. Clearcutting creates real material risks, but Willow's analysis rarely goes farther than the abstraction of protecting "tradition."

In spite of its shortcomings, Strong Hearts, Native Lands contributes to our understanding of the environment as a battleground for social justice. It is a celebration of grassroots activism. It is an empowering story about the assertion of Indigenous rights. I recommend Willow's book for use in the undergraduate classroom as it provides a clear example of Indigenous protest in Canada. Designed, in part, to inspire the youth of Grassy Narrows, Strong Hearts, Native Lands is a poignant reminder that three people and a fallen tree can launch a defense of ten thousand square kilometres of land and the treaty rights guaranteed therein.

\title{
NOTES
}

1 Anton Treuer, The Assassination of Hold in the Day (St. Paul, MN: Borealis Books, 2011), 14.

Brittany Luby

York University

\section{Sotiris Rizas, The Rise of the Left in Southern Europe: Anglo-American Responses (London: Pickering and Chatto, 2012).}

From the late nineteenth century Mediterranean Europe showed markedly different patterns of working-class formation, labour militancy, party building, and socialist institutionalisation than either the Central European and Scandinavian heartlands of social democracy or the mixed labour and peasant territories of the Balkans and Eastern Europe. While not reducible to the contrasting levels of economic development and industrialization, these differences were clearly connected to regional sociologies of development, because agrarian radicalisms of various kinds - for example the rural strengths of anarcho-syndicalism in Spain, or the vital role of the agricultural labourers of the Po Valley in northern Italy centrally shaped the Lefts of their respective countries. Coercive labor regimes in town and country, sharp inequalities of political access, and high levels of state 
violence fed a polarizing dynamic in southern European popular politics that profoundly compromised the space for liberal constitutionalism, helping bring long-lasting forms of authoritarianism to power instead - from Mussolini in Italy and Salazar in Portugal to the successive regimes of Primo de Rivera and Franco in Spain. Yet another distinctive pattern emerged from the years of Nazi occupation during the 1940s, for both Italy and Greece (and the Balkans more generally) produced mass movements of partisan resistance that powerfully structured postwar political culture for many years to come. Strong Communist parties had crystallized from the anti-fascist wartime resistance, with longer-term staying power that likewise distinguished the southern European countries from Europe north of the Alps and east of the Rhine. The strong forms of social democratic corporatism organizing the postwar settlements in the north, which presumed both the legitimacy of trade unions and the necessity of Keynesian and welfarist governing precepts, were also missing in the countries of the south.

None of this bothers the surface of Sotiris Rizas' book, which takes a narrowly institutional view of political process at the level of governments and parties, offering only the thinnest of national narratives, without either historical depth or historiographical context. Focusing on the years between the early 1960s and late 1970s, he provides sequential treatments of Greece (three chapters, 46 pages), Portugal (two chapters, 38 pages), Spain (a single chapter of eighteen pages), and Italy (three chapters, 52 pages). An opening chapter of twelve pages briefly surveys the earlier twentieth century. An Introduction (sixteen pages) and Conclusion (four pages) frame the account. His interest is extremely circumscribed, bounded by the prevailing pattern of British and United States interests and foreign policies in this particular part of the world. While Rizas adds interesting detail from the US and British diplomatic archives (the primary sources for the book), nothing especially new or suprising emerges from this account. The course of events through which a series of democratising challenges to the given bases of political order were contained during this period, country by country, may already by tracked in the copious monographic literatures and salient general accounts, whether in broad outline or in rich casebased detail. To find that "Cold War considerations were preponderant" in US and British policies, that their impact in southern Europe "was significant though not quantifiable," and that this particular story simply confirmed "the tenets and assumptions of the special Anglo-American relationship," if on the basis of the changed post-1945 "power realities that already underpinned the relationship between Washington and London," is not very startling (2).

Unfortunately, Rizas never follows through on his opening claim "that southern Europe as a political concept was mainly a construct of the 1970s," whose meanings emerged specifically from "political developments that signified a rise of the left," in its turn "a problem related directly to the Cold War waged by the superpowers and their allies" (1). If on the one hand the concept's coher- 
ence would need to be grounded in a much richer deep-historical discussion of the kind flagged in my opening paragraph above, then on the other hand its genealogies require far more elaborate analysis of the immediate contexts than this pared-down political narrative remotely allows. Moreover, nowhere is "left" ever defined, allowing Rizas to ignore both the dramatic popular-democratic upsurge of "1968" (i.e. not just the events per se, but all of the surrounding turbulence of 1967-75, including the largest pan-European strike wave since the 1920s) and the later emergence of Eurocommunism (which more than anything else drove the Cold War anxieties of NATO and the US). The more detailed omissions and consequent distortions of the account are far too numerous to mention. For example, the pivotal role of the SPD in both funding and politically shaping the otherwise flimsy implantations of Spanish and Portuguese socialism is entirely effaced by foregrounding the British Labour Party, whose prominence is an artifact of the book's restrictive "Anglo-American" focus. Vast historiographies go unmentioned. Astonishingly, for instance, neither the monographs of Richard Gillespie and Donald Share on the Spanish Socialist Party (each 1989), nor the older classic of Raymond Carr and Juan Pablo Fusi, Spain: Dictatorship to Democracy (1981), nor Pamela Radcliff's recent Making Democratic Citizens in Spain: Civil Society and the Popular Origins of the Transition, 1960-78 (2011) are captured in the bibliography.

Geoff Eley University of Michigan

\section{Judith A. Layzer, Open for Business: Conservatives' Opposition to Enviro- nmental Regulation (Cambridge, MA: MIT Press, 2012).}

The ideological conflicts that have characterized US politics over the past few decades are rarely as apparent as they are in environmental policy. In Open for Business, Judith Layzer carefully documents these policy debates over the last four decades of modern environmental politics. The result is a detailed and insightful narrative of the role of political conservatives in shaping environmental regulation. This conservative influence has been well coordinated, sustained over many decades, and effective in impeding progress, if not in rolling back basic environmental protections. The consequences for the nation and, given the need for US leadership, for the world are profound.

The book includes a chapter on policy theory as a framework for analyzing the influence of conservative ideas and politics. This is a useful review in its own right, but is not essential for following the story in the book. Except for the conclusion, the remaining chapters are organized chronologically, beginning with the "environmental decade" of the 1970s and following the story from the Reagan 